\title{
ASSESSING THE ROLE OF INTERPERSONAL AND INFORMATIONAL JUSTICE IN THE PURVIEW OF TEACHING FACULTY'S JOB SATISFACTION
}

\author{
Abdullah $^{1 *}$, Niaz Muhammad ${ }^{2}$, Arshad Khan Bangash ${ }^{3}$, Nizar Ahmad ${ }^{4}$, Ihsan Ullah Khan ${ }^{5}$ \\ ${ }^{1 *, 4}$ Lecturer in Sociology, Department of Sociology and Political Sciences, Bacha Khan University, Charsadda, Pakistan; \\ ${ }^{2}$ Professor \& Chairman, Department of Sociology, University of Peshawar, Pakistan; ${ }^{3}$ Assistant Professor, Department \\ of Sociology and Political Sciences, Bacha Khan University, Charsadda, Pakistan; ${ }^{5}$ Lecturer in Sociology, Department \\ of Sociology, FATA University, NMD, Kohat, Pakistan. \\ Email: 1" ${ }^{*}$ abdullahsoc3@gmail.com, ${ }^{2}$ niaz@uop.edu.pk, ${ }^{3}$ arshad.dwhh@gmail.com, ${ }^{4}$ nizardirvi@gmail.com, \\ 5ihsansoc@fu.edu.pk
}

Article History: Received on $17^{\text {sth }}$ March 2021, Revised on $29^{\text {th }}$ June 2021, Published on $30^{\text {th }}$ June 2021

\begin{abstract}
Purpose of the study: This study was designed to assess the role of interpersonal and Informational Justice in the purview of teaching faculty's job satisfaction.

Methodology: A cross-sectional and quantitative research method was carried out in three randomly selected universities of Khyber Pakhtunkhwa, Pakistan i.e. Bacha Khan University, University of Malakand, and the University of Swat. A well-structured questionnaire was used for data collection from 217 sampled respondents (employees) for primary data collection. Further, the researchers analyzed the data through descriptive and inferential statistics, i.e. frequency, percentage, correlation, and indexation of the study variables, namely dependent (job satisfaction) and independent (Interpersonal and Informational Justice), respectively.
\end{abstract}

Principal Findings: Regarding the demographic sketch of the sampled respondents, the study found that the majority of the respondents were male, having the age group from 31-40 years with the collaboration of 5-10 year experiences of teaching at the university level. Further, as per the correlation test statistics at bivariate analysis between the Interpersonal and Informational Justice with job satisfaction was found significant with strong correlation (P $\leq 0.05$; $0.860)$ respectively.

Applications of this study: The government and administration should take positive steps to provide a good working environment to establish their trust by expanding cooperation towards employees, exploration of benefits, strengthening relationships with each other, and encouragement of open communication that can stimulate and encourage an exchange of view between faculty and administration was put forward some of the recommendations in light of the study findings.

Novelty/Originality of this study: This research comes under the domain of Sociology of organization and sociology of work through the perceptional-based endeavor.

Keywords: Interactional Justice, Interpersonal Justice, Informational Justice, Job Satisfaction, Teaching Faculty, Correlation, Indexation.

\section{INTRODUCTION}

Job satisfaction refers to the pleasant and positive emotions that arise during the experience of a job (Chamundeswari, $\underline{2013})$. Teachers can sense these feelings when the organizational values become equal to the needed values (Okray and Cakici, 2008; Nie et al., 2015). Interpersonal and informational aspects of justice are among the most influential factors influencing teaching faculty's job satisfaction (Iqbal, 2013; Rupp et al., 2014; Karim et al., 2017; Sia and Tan, 2016). Satisfied employees exhibit loyalty, an innovative attitude for continuous betterment, and more involvement in the decision origination process in the organization's best interest (Jin et al., 2018; Yang et al., 2011; Ghazzawi, 2017). It has been identified as a critical variable in predicting organizational outcomes, including employees' relationships with administration, absenteeism, and turnover intentions among teaching faculty (Mundhra, 2010; Mohsan et al., 2011; Hayati \& Caniago, 2012; Dicke et al., 2020).

Producing skilled humans to triumph over the impediments to the development of a nation is the fundamental purpose of education, which can only be achieved with a satisfied workforce (Scott, 2006; Duffy \& Lent, 2009). Teachers who are satisfied with their jobs put time, effort, and energy; hence, resulting in increased productivity (Kalisch et al., 2006; \& Dekoulou and Trivellas, 2015; Skaalvik \& Skaalvik, 2014). An institution can achieve their desired goals only if they prioritize increasing job satisfaction among their employees (Badri et al., 2013; Demirdag, 2015). Teachers are the essential assets of educational institutions. Dynamic institutions make every potential effort to hire the right employees (Bolin, 2007) and keep them working passionately to progress and achieve institutional goals (Rahman et al., 2017; Tang et al., 2014).

\section{Interpersonal and Informational aspects of justice}

Interpersonal and informational aspects of justice refer to the way organizations treat their employees during the decision-making process (Lim and Loosemore, 2017). It refers to the interpersonal communication and dealings between 
employer and employee (Wang, Lu, Siu, 2015). Employees tended to show optimistic organizational behaviour and try to collaborate in resolving the organizational problems when they perceive that the working environment is favourable, just (Ambrose et al., 2013), and unbiased (Imani et al., 2019). Interpersonal and informational aspects of justice have been recognized as the critical modules to improve teachers' performance, dignity, and academic outcomes (Leineweber et al., 2017). Quality graduates are acknowledged as the result of excellent teachers' contributions. Among several factors, interpersonal and informational aspects of justice are the factors that influence teachers' performance at higher educational institutions (Graso et al., 2014). Teachers anticipate fair treatment and a better work environment concerning the contribution and efforts they put into the organization (Kalay, 2016). They expect dignity, respect, equal treatment, esteem, compelling voice, trust, and a sense of security (Capuano, 2016). Hence, interpersonal and informational aspects of justice are considered significant factors leading to the success of any project (Moldavanova, 2018).

Several studies have shown that personal growth (Fatt et al., 2010), confidence, and positive relationships were linked with interactional justice (Ambrose et al., 2013). Two main aspects of interactional aspects have been proposed. Interpersonal justice focuses on the quality of employer interaction with employees to treat them with respect and dignity (Haarhaus, 2018). However, the 2nd aspect of interactional justice, informational justice, is primarily related to the organizational information regarding procedures that affect employees (Di Fabio and Kenny, 2019). Moreover, interactional justice is also linked with intrinsic factors, i.e., motivation, autonomy, and growth (Bakotic, 2016). The fairness of treating employees with respect and dignity can be evaluated by how the administrators were unbiased, truthful, and caring in making the decision or laying the foundation for it (Zainalipour et al., 2010).

The most significant determinants of interactional justice are interpersonal communication, sufficient explanation (Abdullah et al., 2019), truthfulness, access to influence on decision-making procedures (Ghran et al., 2019), honesty, empathy, kindness, deliberation, and taking decisions on the rational ground (Altahayneh et al., 2014). Moreover, poor administrators attitude negatively affect employees' motivation to work (Groen, 2018).

Teachers are morally obliged to serve the country's development, as education is broadly acknowledged as one of the significant indicators of development (Sharma and Jyoti, 2009). Jaiyeoba and Jibril (2008) indicated that motivated and satisfied teachers showed more progress. The success and failure of the educational institution depend on the way an organization treats its employees (Ofoegbu, 2004).

\section{Theoretical Framework}

Luthan (1998) demonstrated that employees find it easier to work when they get a pleasant environment. Accomplishing the tasks and goals are difficult in an unpleasant work environment. He applied this model to teachers; as stated, it is difficult for teachers to put the desired potential and devotion in their respective professions if their moral diversity and dignity are affected. The Social Exchange Theory of George Homans is also related to the topic. According to the theory, people compare their outcomes linked with their contributions (Cook and Gerbasi, 2006). People would try to do more work and effort if they were awarded for them in the past. It means that sanctions for something in the past motivate or de-motivate people. The core principle of this theory is that the relationship between social entities is the degree to which each of these two social entities agreed-upon exchange implicitly norms, and respect social rules. Examples of these attributes define the quality of relationships such as loyalty, trust, and commitment. These attributes depend upon status, goods, love, money, and services that employees invest in social relationships (Harkness \& Schier, 2011).

\section{Statement of the problem}

Justice is essential in every sphere of life, and the same becomes more significant within the organizational structure. Interpersonal and informational aspects of justice are the standards applied to how employees relate to each other at work, influencing work performance and job satisfaction. Interpersonal and informational aspects of justice are important in educational institutions. The administration is responsible for creating a productive and positive work environment, which requires a fair, honest, and respectful way to deal with and interact with teachers. Teachers expect the administration to provide satisfactory explanations about decision-making and to communicate the relevant information sincerely. In Pakistani society, justice within the organization is an area to be researched, as most people do not show signs of happiness with the unfair treatment, organizational rules, and procedures. In most cases, employees are not treated fairly; hence, leading to job dissatisfaction and turnover intention. The present study was conducted to know about teaching faculty's job satisfaction. The research activity focused on the interpersonal and informational aspects of the justice system and their cause and effect relation with teachers' job satisfaction at higher educational institutions.

\section{MATERIAL AND METHODS}

The present study was carried out in 3 randomly selected universities of Khyber Pakhtunkhwa, Pakistan, i.e., Bacha Khan University, University of Malakand, and University of Swat. The nature of the study was quantitative, and a questionnaire was used as a tool of data collection for collecting information from the sample size of 217 respondents selected through the proportional allocation method. A conceptual framework consists of independent variables, i.e., interpersonal and informational aspects of justice, and a dependent variable, i.e., job satisfaction, was cross-tabulated 
through the application of Chi-Square test statistics to ascertain the association between the dependent and independent variables with the amalgamation of correlational test statistics at the bivariate level.

\section{RESULTS AND DISCUSSION}

Based on the socioeconomic sketch of the sampled respondents, (SR), as disclosed in the table (1), highlighted that majority $(n=217,82.9 \%)$ of the SR were male having $(n=217,82.9 \%)$, followed by $(n=217,73.7 \%)$ were of the age group of 31-40 years. Further, majority $(n=217,83.9 \%)$ were unmarried. In addition, $(n=217,55.3 \%)$ were affiliated with the field of science. Similarly, $(\mathrm{n}=217,78.3 \%)$ had MS educational qualifications in their respective academics, and $(\mathrm{n}=217,58.5 \%)$ had 5-10 years of overall job experience in the respective organization. Keeping in view the preceding results, it is pertinent to mention that most of the sampled respondents were male due to the persistent nature of Pukhtunwali with the amalgamation of the patriarchal structure that impede women from all walks of life generally while the attainment of job particularly (Abdullah et al., 2019). Likewise, science is a field, which is more diverse and had a profound job market in developing countries. At the same time, the Pakistan scenario notably led the educated masses to get insight into the domain of science due to securing future repercussions. This result was consonant with the findings of Taylor (2007), who found that science's teachers of environmental engineering, agricultural sciences, and geosciences expected the highest salaries. These teachers' expected and accepted salaries were much higher than the mean minimum salaries indicated by teachers of social sciences. In addition, the majority of the SR had their age group from 31-40 years along with 55\% were unmarried due to the existential nature of being secure in all walks of life; thus, delayed marriages were preferred as per attainment of education and job respectively. In this regard, Khan (2010) disclosed that the age of respondents is essential in a sense because the data collected from them provide a better understanding of the problem. Similarly, as Dorasamy and Letooane (2015) found, higher education is necessary for career advancement and identified as a significant factor leading to job satisfaction among employees. Moreover, higher education is compulsory for attaining a lecturer job at the universities level as per governmental policy.

Table 1: Showing the Demographic profile of the respondents

\begin{tabular}{|c|c|c|c|c|}
\hline \multirow[t]{2}{*}{ Characteristics of the sampled respondents } & \multirow[t]{2}{*}{ Frequency $(\%)$} & \multicolumn{3}{|c|}{ The Measure of Central Tendency } \\
\hline & & Mean & Median & Mode \\
\hline Gender & & 1.17 & 1.00 & 1 \\
\hline Male & $180(82.9)$ & & & \\
\hline Female & $37(17.1)$ & & & \\
\hline$\underline{\text { Age }}$ & & 2.08 & 2.00 & 2 \\
\hline Below 30 & $20(9.2)$ & & & \\
\hline $31-40$ & $160(73.7)$ & & & \\
\hline Above 40 & $37(17.1)$ & & & \\
\hline Marital status & & 1.84 & 2.00 & 2 \\
\hline Married & $35(16.1)$ & & & \\
\hline Unmarried & $182(83.9)$ & & & \\
\hline Divorced & $0(0.0)$ & & & \\
\hline Faculty & & 1.71 & 1.00 & 2 \\
\hline Arts and humanities & $40(18.4)$ & & & \\
\hline Biological Science & $120(55.3)$ & & & \\
\hline Social Science & $57(26.3)$ & & & \\
\hline Educational Qualification (year) & & 2.22 & 2.00 & 2 \\
\hline MS & $170(78.3)$ & & & \\
\hline $\mathrm{PhD}$ & $47(21.7)$ & & & \\
\hline Overall job Experience (year) & & 2.05 & 2.00 & 2 \\
\hline Less than 5 & $40(18.4)$ & & & \\
\hline $5-10$ & $127(58.5)$ & & & \\
\hline Above 10 & $50(23.0)$ & & & \\
\hline
\end{tabular}

Source: Author(s)

\section{Job satisfaction (Dependent Variable)}

Regarding job satisfaction (JS), as illustrated in the table (2), the majority (63.1\%) of the sample respondents stated that they were not satisfied with the administration's attitude towards them. It can be deduced from the findings that the university administration is not cooperative with teachers. They intentionally developed such types of behavior and attitudes toward teachers to maintain their influence over faculty members. This result is consistent with the findings of Park (2016), which showed that administrators who are not careful about their attitudes toward employees and demonstrate negative attitudes toward them; thus, result in a tremendously negative impact for an organization and turnover intentions among employees. In addition, the poor and rude administrators' attitudes negatively affect employees' motivation to work. 
Similarly, (81.6\%) of the respondents stated that the working environment does not satisfy them. It can be deduced from the findings that the working environment is not favourable for teachers. In line with this, $\underline{\text { Saraih }(2019)}$ ) found that a better working environment is required to increase job commitment among employees. Further, the working environment inside an organization has negative impacts on employee performance (Raziq and Maulabakhsh, 2015; Skalli et al., 2008). Furthermore, the majority of the respondents $(55.8 \%)$ were not satisfied with the procedures. Likewise, Bilal et al. (2015) found that dissatisfied employees from organizational procedures eventually harm the overall organization performance because employees' discontent results in high turnover intentions.

Moreover, $(78.3 \%)$ of the respondents stated that they were not satisfied by the opportunity to share their opinion at work. It can be deduced that teachers opinions and suggestions are neither encouraged nor welcomed by the administration. These results were in line with the findings of Ouyang et al. (2015) that communicating ideas and having the confidence to speak up are the qualities, which are most welcome in the workplace. Employees feel dissatisfied when the administrators and colleagues do not appreciate their opinion and ideas.

Likewise, $(62.7 \%)$ of the respondents stated that they are not satisfied with the workload distribution. It could be the reason that some of the teachers are assigned more and extra workload of courses. It might also be the reason that various responsibilities of office work are assigned to them. This result is consonant with Ali and Farooqi's (2014) findings that teachers were given different workload levels daily. However, any changes in the workload can alter the stress level among them. Moreover, teachers' perception of fairness regarding workload can also be changed if given extra workload. An increase in workload has severe effects on job satisfaction, and eventually, it affects job performance.

In addition, (65.0\%) of the respondents proclaimed that they are not satisfied with the occupational facilities. It might be why teachers are not encouraged in career advancements such as further studies or study leave. Due to the administration's nepotism, only some teachers are provided with every kind of occupational facility; however, the rest of the teachers were discouraged to continue their further education. In this regard, Hussein et al. (2017) stated that most of the university's teachers continue their higher studies after getting jobs; however, some of the institutions restrict teachers to either stay with the organization or continue their studies. Therefore, they are not interested in continuing their jobs; hence, they opt to quit the organization.

Moreover, that $(81.6 \%)$ of the respondents answered that they are not satisfied with the accommodation facilities. It could be the reason that there are no proper facilities of accommodation for the teachers. Most of these university teachers do not have accommodation facilities; therefore, they go home every day, which costs too much. This result is consistent with Ongori's (2013) findings that most organizations provide accommodations facilities to their employees to maintain their attendance and keep them satisfied. The study further indicated that high turnover and dissatisfaction with the job was found among those employees who were not provided with any accommodation facilities by the concerned organizations.

Table 2: Perceptions of the sampled respondents about JS

\begin{tabular}{llll}
\hline Attributes & Yes (\%) & No (\%) & Uncertain (\%) \\
\hline Satisfaction with the administration attitudes towards teachers & $72(33.2)$ & $137(63.1)$ & $8(3.7)$ \\
\hline Satisfaction from the working environment & $32(14.7)$ & $177(81.6)$ & $8(3.7)$ \\
\hline Satisfaction from the procedure & $90(41.5)$ & $121(55.8)$ & $6(2.8)$ \\
\hline Opportunity to share your opinion at work & $35(16.1)$ & $170(78.3)$ & $12(5.5)$ \\
\hline Satisfaction from the distribution of workload & $65(30.0)$ & $136(62.7)$ & $16(7.4)$ \\
\hline Occupational facilities & $32(14.7)$ & $141(65.0)$ & $44(20.3)$ \\
\hline Accommodation facilities & $32(14.7)$ & $177(81.6)$ & $08(3.7)$ \\
\hline
\end{tabular}

Source: Field Survey, 2018

\section{Perception of sampled respondents regarding I\&IAJ (independent variable)}

Regarding I\&AJ, the majority (87\%) of the sampled respondents negated that they were treated politely in their respective organizations. It can be deduced from the findings that the administration does not courteously treat the university's teachers. None of the employees wants to feel as if they are being mistreated. Teachers, if treated politely, can deliver better outcomes. The level of their efforts depends on the way the administration treats them. These results were consonant with Addai et al. (2018), who found that the most desirable things employees expected from the administration were to be treated with dignity and polite manner. The study further revealed that near half of the employees reported the rude behaviour of the administration. Likewise, Younas et al. (2020) demonstrated that the positive workplace culture was harmed by the abrasive and harsh conversation between administration and teachers.

Likewise, $(82 \%)$ disclosed that the administrator did not treat them equally. Equality in the workplace plays a pivotal role in job satisfaction. Unequal treatment of teachers and nepotism by the administrators may lead to uncertainties. Teachers getting unequal treatment may feel embarrassed among colleagues, which decrease their job satisfaction. As witnessed by Hassan (2012), that the design and operation of legal and political institutions are based on the idea of fair 
and equitable treatment. Organizational fairness is more than just a moral consideration; it has ramifications for both employees' economic and psychological well-being by meeting various socio-emotional demands in the workplace. In the line with above, Qureshi et al. (2013) stated that employees treated equally at work have a high degree of trust and satisfaction and are less inclined to leave the organization.

In addition, the majority, $69.1 \%$ of the SR stated that the administration does not respect them. Every teacher deserve respect either outside of society or at the workplace. The administration should understand the dignity and value of nation builders. This result is in line with the findings of Haryoni et al. (2019) found that the availability of a fair atmosphere in which employees can have equal chances and be treated with respect is linked to the intention of employees to stay with the organization. Similarly, Gadelrab et al. (2020) identified that interpersonal treatment is assessed based on the extent to which authorities respect employees. Employees were found happy, and job satisfaction was observed high when the administrators treated them with respect.

In addition, $(57.6 \%)$ of the respondents revealed that the administrators do not provide any safeguard to teachers in case of any violation of rules. It could be deduced that employees are bound to the rules regulation of the concerned organization, and are expected to follow them strictly. They are not provided with any sort of support and safeguard and are dealt strictly with rules in case of any breach of law. Similarly, Song and Yang (2020) stated that there are two reasons behind this: firstly, the administration is not interested in solving teachers' issues, and secondly, the administration is aware that safeguarding is sheltered by several laws and legal frameworks. Therefore, they did not support teachers in case of any breach of law.

Further, the findings of the study indicated that the majority $(80.6 \%)$ of the respondents were of the view that the administration does not share any organizational information with them. Corporate data is worth to teachers because it includes many decisions regarding their outcomes. In this regard, Akram et al. (2020) have pointed out that fair executive policies are possible only if the organizational information flow effectively in a good manner. They further explained that administrators' appropriate decisions are not enough for the teachers if valuable sharing and communication do not support it.

Similarly, $80 \%$ and $62 \%$ of the SR stated that the administrators were dishonest to share the organizational information, respectively. It can be deduced that the administration was corrupt in sharing administrative information with teachers. In this regard, Mulyana et al. (2020) stated that the most apparent result of corporate dishonesty is that it has a bad reputation amongst teachers since it does not share relevant information.

Furthermore, $(73.7 \%)$ of the respondents stated that administrators do not communicate the details related to the taken decision in a timely manner. Communication of further information promptly can increase the trust and commitment among teachers to the concerned organization. In line with this result, Hadi et al. (2020) stated that employees always cared about truthful, appropriate and timely explanations of decisions because they are curious about their position and outcomes. In addition, Planning, organizing, directing, and controlling are all administration functions that rely on good communication.

However, the majority (64\%) of the SR stated that the administration fulfilled faculty needs regarding official correspondence. Fulfilling faculty needs regarding official correspondence is the responsibility of administration at any organization, and it might be why the administration in higher educational institutions is fulfilling teachers' needs. It could also be the reason that in case of not fulfilling teachers' needs, the teachers may go to higher authorities for complaints. This result was consonant with the findings of Awang and Ahmad (2015), who found that fulfilling the official needs of teachers is the duty and responsibility of the administration. Likewise, the administration's tasks include responding and resolving the academic difficulties of teachers, as well as coordinating with teachers to meet their formal correspondence requirements.

Moreover, (78\%) of the respondents stated that they did not trust their administrators regarding fair treatment. Trust plays a vital role in teachers' commitment to their organization. They only trust the administration if they observe appropriate treatment. The administration is inclined towards some specific teachers, and all the teachers did not get equal and appropriate treatment. In this regard, Bandura et al. (2019) stated that building trust between employees and administrators is necessary for an organization. The administrator's proper behaviour makes employees feel more confident to understand their exact dignity among colleagues in an organization. It was further explained that employees were found more motivated to work when their confidence was increased. Likewise, Latsch (2017) found that one of the most essential factors in universities is trust. Much of a university's operation is influenced by conviction, and it is a valuable resource for administration when they embark on reform programs or academic policies.

Table 3: Perception regarding I\&AJ (independent variable)

\begin{tabular}{llll}
\hline Statement & Yes(\%) & No(\%) & Uncertain(\%) \\
\hline Treatment in a polite manner & $27(12.4)$ & $190(87.6)$ & $0(0.0)$ \\
\hline Treat faculty members equally & $20(9.2)$ & $180(82.9)$ & $17(7.8)$ \\
\hline Respect faculty members & $60(27.6)$ & $125(69.1)$ & $07(3.2)$ \\
\hline Provide safeguard to faculty members & $22(10.1)$ & $125(57.6)$ & $70(32.3)$ \\
\hline
\end{tabular}




\begin{tabular}{llll}
\hline Sharing organizational information & $42(19.4)$ & $175(80.6)$ & $0(0.0)$ \\
\hline Sincerely and honestly communication & $58(26.7)$ & $135(62.2)$ & $24(11.1)$ \\
\hline Decide the decision in a timely manner & $50(23.0)$ & $160(73.7)$ & $07(3.2)$ \\
\hline Fulfil faculty needs regarding official correspondence & $140(64.5)$ & $65(30.0)$ & $12(5.5)$ \\
\hline Trust in term of fair treatment & $40(18.4)$ & $170(78.3)$ & $07(3.2)$ \\
\hline
\end{tabular}

Source: Field Survey, 2018

\section{Correlation of bivariate analysis through indexation of IAJ and JS}

Further, as per correlation test statistics at bivariate analysis between the interpersonal and informational aspects of justice (independent variable) and job satisfaction (dependent variable) as shown the table (4) disclosed a significant and strong correlation $(\mathrm{p}=0.000 ; 0.860)$, respectively. It could be deduced from these findings that the interpersonal and informational aspects of justice are positively correlated with job satisfaction. These results were also in line with Jamal (2020); Dang and Pham (2020); Inoue et al. (2013); Ghani et al. (2020) alluded that, the interpersonal and informational dynamics in terms of organizational information, honest communication, explanation of decision-making procedure, the mechanized transmission of information about such sort of activities with the collaboration of employee trust, respect were found positively correlated in their respective studies. In addition, all the capabilities mentioned above of the administrators may enhance the efficiency of job satisfaction level in each organization and vice versa.

Table 4: Correlation of bivariate analysis through indexation of IAJ and JS

\begin{tabular}{|c|c|c|c|}
\hline \multicolumn{2}{|c|}{ Correlation statistics } & IAJ & JS \\
\hline \multirow[t]{5}{*}{ IAJ } & Pearson Correlation & 1 & $.860^{* *}$ \\
\hline & Sig. (2-tailed) & & .000 \\
\hline & Sum of Squares and Cross-products & 119.075 & 698.059 \\
\hline & Covariance & .564 & 3.308 \\
\hline & $\mathrm{N}$ & 212 & 212 \\
\hline \multirow[t]{5}{*}{ JS } & Pearson Correlation & $.860^{* *}$ & 1 \\
\hline & Sig. (2-tailed) & .000 & \\
\hline & Sum of Squares and Cross-products & 698.059 & 5726.832 \\
\hline & Covariance & 3.308 & 26.513 \\
\hline & $\mathrm{N}$ & 212 & 217 \\
\hline
\end{tabular}

Note**. Correlation is significant at the 0.01 level (2-tailed); JS (Jo Satisfaction), and IAJ (Interpersonal and Informational aspects of justice)

\section{Indexation of the independent and dependent variable through the application of bivariate analysis}

Furthermore, table (5) showed the association at bivariate level (through indexation of both dependent and 1 independent variable) is disclosed as $\left(\mathrm{p}=0.000, \mathrm{~T}^{\mathrm{b}}=56.845\right)$ by showing highly significant association with positive direction between the variables respectively.

Table 5: Indexation of the independent and dependent variable through the application of bivariate analysis

\begin{tabular}{lll}
\hline Indexed Dependent variable & Indexed independent variable & Chi-square and P vale \\
\hline Job satisfaction & Interpersonal \& Informational aspects of Justice & $\mathrm{X}^{2}=362.327 \mathrm{P}=0.000$ \\
& & $\mathrm{~T}^{\mathrm{b}}=56.845$ \\
\hline
\end{tabular}

\section{CONCLUSION AND RECOMMENDATIONS}

This study concluded that the university administration unfairly and unequally treats majority of the university teachers. They were strictly dealt with the rule in case of any breach of law. Further, the university administration is dishonest and insincere with teachers. Similarly, teachers are not provided with any explanation of decision-making procedures. Moreover, they do not trust the university administration in terms of fair treatment because the administration does not take decisions in a timely manner and hide organizational information from teachers. The study recommends that the government and administration should take positive steps to provide a positive working environment and should establish their trust by expanding cooperation towards employees and strengthen employee relationships with each other.

\section{STUDY LIMITATIONS}

A longitudinal research design will be required for this study due to human dynamism and the prevalence of job good attitudes. Moreover, a large sample size is needed for further studies that cover a broad area, including procedural and distributive justice is also needed to overcome the subject in the field of sociology of work.

\section{ACKNOWLEDGEMENT}

The researchers acknowledged all the study participants of the study area, along with Bacha Khan University Charsadda, 
for awarding the Mphil degree to the Principal author Mr. Abdullah.

\section{AUTHORS CONTRIBUTION}

Abdullah is the principal and corresponding author of this manuscript. Prof. Dr. Niaz Muhammad proofread the final manuscript. Dr. Arshad Khan Bangash was the major supervisor. Dr. Nizar Ahmad designed the statistical application of this article. Dr. Ihsan Ullah assisted the data collection team with the collaboration of support of review in chronological order.

\section{REFERENCES}

1. Abdullah., Bangash, A. K., \& Kaleem, M. (2019). Effects Of Interactional Justice On Teaching Faculty’s Job Satisfaction. Pakistan Journal Of Society, Education And Language (PJSEL), 5(1), 1-13.

2. Addai, P., Kyeremeh, E., Abdulai, W., \& Sarfo, J. O. (2018). Organizational Justice and Job Satisfaction as Predictors of Turnover Intentions among Teachers in the Offinso South District of Ghana. European Journal of Contemporary Education, 7(2), 235-243. https://doi.org/10.13187/ejced.2018.2.235

3. Akram, T., Lei, S., Haider, M. J., \& Hussain, S. T. (2020). The impact of organizational justice on employee innovative work behavior: Mediating role of knowledge sharing. Journal of Innovation \& Knowledge, 5(2), 117-129. https://doi.org/10.1016/j.jik.2019.10.001

4. Ali, S., \& Farooqi, Y. A. (2014). Effect of work overload on job satisfaction, the effect of job satisfaction on employee performance and employee engagement (a case of the public sector the University of Gujranwala Division). International Journal of Multidisciplinary Sciences and Engineering, 5(8), 23-30.

5. Altahayneh, Z. L., Khasawneh, A., \& Abedalhafiz, A. (2014). Relationship between organizational justice and job satisfaction as perceived by Jordanian physical education teachers. Asian Social Science, 10(4), 131-138. https://doi.org/10.5539/ass.v10n4p131

6. Ambrose, M. L., Schminke, M., \& Mayer, D. M. (2013). Trickle-down effects of supervisor perceptions of interactional justice: A moderated mediation approach. Journal of Applied Psychology, 98(4), 678. https://doi.org/10.1037/a0032080

7. Awang, R., \& Ahmad, W. M. R. W. (2015). The impact of organizational justice on organizational citizenship behavior in Malaysian higher education. Mediterranean Journal of Social Sciences, 6(5), 674-674. https://doi.org/10.5901/mjss.2015.v6n5s2p674

8. Badri, M. A., Mohaidat, J., Ferrandino, V., \& El Mourad, T. (2013). The social cognitive model of job satisfaction among teachers: Testing and validation. International Journal of Educational Research, 57, 12-24. https://doi.org/10.1016/j.ijer.2012.10.007

9. Bakotić, D. (2016). Relationship between job satisfaction and organisational performance. Economic researchEkonomska istraživanja, 29(1), 118-130. https://doi.org/10.1080/1331677X.2016.1163946

10. Bandura, C. T., Kavussanu, M., \& Ong, C. W. (2019). Authentic leadership and task cohesion: The mediating role of trust and team sacrifice. Group Dynamics: Theory, Research, and Practice, 23(3-4), 185. https://doi.org/10.1037/gdn0000105

11. Bilal, A. R., Muqadas, F., \& Khalid, S. (2015). Impact of organizational justice on job satisfaction with mediating role of psychological ownership. Global Management Journal for Academic \& Corporate Studies, 5(2), 63.

12. Bolin, F. (2007). A study of teacher job satisfaction and factors that influence it. Chinese Education \& Society, 40(5), 47-64. https://doi.org/10.2753/CED1061-1932400506

13. Capuano, A. (2016). Giving Meaning to Social Origin in International Labour Organization (ILO) Conventions, the Fair Work Act 2009 (CTH) and the Australian Human Rights Commission Act 1986 (CTH): Class Discrimination and Its Relevance to the Australian Context. UNSWLJ, 39, 84.

14. Chamundeswari, S. 2. (2013). Job satisfaction and performance of school teachers. International Journal of Academic Research in Business and Social Sciences, 3(5), 420.

15. Cook, K. S., Cheshire, C., \& Gerbasi, A. (2006). Power, dependence, and social exchange (pp. 194-216).

16. Dang, T. T., \& Pham, A. D. (2020). What make banks' front-line staff more customer oriented? The role of interactional justice. International Journal of Bank Marketing. https://doi.org/10.1108/IJBM-09-2019-0321

17. Dekoulou, P., \& Trivellas, P. (2015). Measuring the impact of learning organization on job satisfaction and individual performance in Greek advertising sector. Procedia-Social and Behavioral Sciences, 175, 367-375. https://doi.org/10.1016/j.sbspro.2015.01.1212

18. Demirdag, S. (2015). Assessing teacher self-efficacy and job satisfaction: Middle school teachers. Journal of Educational and Instructional Studies in the World, 5(3), 35-43.

19. Di Fabio, A., \& Kenny, M. E. (2019). Resources for enhancing employee and organizational wellbeing beyond personality traits: The promise of Emotional Intelligence and Positive Relational Management. Personality and Individual Differences, 151, 109278. https://doi.org/10.1016/j.paid.2019.02.022

20. Dicke, T., Marsh, H. W., Parker, P. D., Guo, J., Riley, P., \& Waldeyer, J. (2020). Job satisfaction of teachers and their principals in relation to climate and student achievement. Journal of educational psychology, 112(5), 1061. https://doi.org/10.1037/edu0000409 
21. Dorasamy, N., \& Letooane, M. K. (2015). Job and career satisfaction in higher education institutions: a case study of university "A" in South Africa. Problems and perspectives in management.

22. Duffy, R. D., \& Lent, R. W. (2009). Test of a social cognitive model of work satisfaction in teachers. Journal of Vocational Behavior, 75(2), 212-223. https://doi.org/10.1016/j.jvb.2009.06.001

23. Fatt, C. K., Khin, E. W. S., \& Heng, T. N. (2010). The impact of organizational justice on employee's job satisfaction: The Malaysian companies perspectives. American Journal of Economics and Business Administration, 2(1), 56-63. https://doi.org/10.3844/ajebasp.2010.56.63

24. Gadelrab, H. F., Alkhadher, O., Aldhafri, S., Almoshawah, S., Khatatba, Y., El Abiddine, F. Z., \& Slimene, S. (2020). Organizational justice in Arab Countries: Investigation of the measurement and structural invariance. Cross-Cultural Research, 54(1), 3-27. https://doi.org/10.1177/1069397118815099

25. Ghazzawi, I. A. (2017). Organizational turnaround: A conceptual framework and research agenda. American Journal of Management, 17(7), 9-23. https://doi.org/10.33423/ajm.v17i7.1698

26. Ghani, U., Zhai, X., Spector, J. M., Chen, N. S., Lin, L., Ding, D., \& Usman, M. (2020). Knowledge hiding in higher education: Role of interactional justice and professional commitment. Higher Education, 79(2), 325-344. https://doi.org/10.1007/s10734-019-00412-5

27. Ghran, L. A. Z., Jameel, A. S., \& Ahmad, A. R. (2019). The effect of organizational justice on job satisfaction among secondary school teachers. International Review, 3(4), 84-93.

28. Graso, M., Jiang, L., Probst, T. M., \& Benson, W. L. (2014). Cross-level effects of procedural justice perceptions on faculty trust. Journal of Trust Research,4(2), 147-166. https://doi.org/10.1080/21515581. $\underline{2014.966830}$

29. Groen, B. A. (2018). A survey study into participation in goal setting, fairness, and goal commitment: Effects of including multiple types of fairness. Journal of Management Accounting Research,30(2), 207-240. https://doi.org/10.2308/jmar-52072

30. Haarhaus, B. (2018). Uncovering cognitive and affective sources of satisfaction homogeneity in work teams. Group Processes \& Intergroup Relations, 21(4), 646-668. https://doi.org/10.1177/1368430216684542

31. Hadi, S., Tjahjono, H. K., \& Palupi, M. (2020). Study of organizational justice in smes and positive consequences: Systematic review. International Journal of Advanced Science and Technology, 29(03), 47174730 .

32. Haryono, S., Ambarwati, Y. I., \& Saad, M. S. M. (2019). Do organizational climate and organizational justice enhance job performance through job satisfaction? A study of Indonesian employees. Academy of Strategic Management Journal, 18(1), 1-6.

33. Harkness, P., \& Schier, M. (2011). Performance related pay in Australian universities: the case of Swinburne university. Australian Universities' Review, The, 53(2), 50-58.

34. Hassan, M., Akram, A., \& Naz, S. (2012). The relationship between person organization fit, person-job-fit and turnover intention in banking sector of Pakistan: The mediating role of psychological climate. International Journal of Human Resource Studies, 2(3), 172. https://doi.org/10.5296/ijhrs.v2i3.2286

35. Hayati, K., \& Caniago, I. (2012). Islamic work ethic: The role of intrinsic motivation, job satisfaction, organizational commitment and job performance. Procedia-Social and Behavioral Sciences, 65, 1102-1106. https://doi.org/10.1016/j.sbspro.2014.05.148

36. Hussein, N., Razak, N. A. A., \& Omar, M. K. (2017). Learning Organization and work engagement: an empirical evidence of a higher Learning Institution in Malaysia. Information Management and Business Review, 9(1), 17-22. https://doi.org/10.22610/imbr.v9i1.1592

37. Imani, H., Gholipour, A., Azar, A., \& Pourezzat, A. A. (2019). Identifying components of staffing system to develop administrative integrity. Journal of Public Administration, 11(2), 251-284.

38. Inoue, A., Kawakami, N., Tsuno, K., Tomioka, K., \& Nakanishi, M. (2013). Organizational justice and psychological distress among permanent and non-permanent employees in Japan: a prospective cohort study. International journal of behavioral medicine, 20(2), 265-276. https://doi.org/10.1007/s12529-012-92247

39. Iqbal, K. (2013). Determinants of organizational justice and its impact on job satisfaction. A Pakistan base survey. International review of management and business research, 2(1), 48-56.

40. Jaiyeoba, A. O., \& Jibril, M. A. (2008). A study of job satisfaction of secondary school administrators in Kano state, Nigeria. African Research Review, 2(2), 94-107. https://doi.org/10.4314/afrrev.v2i2.41044

41. Jamal, A. (2020, October). The role of moderation of job satisfaction and religiosity in influencing organizational justice on employee performance. In 1st International Conference of Business and Social Sciences.

42. Jin, M. H., McDonald, B., \& Park, J. (2018). Person-organization fit and turnover intention: Exploring the mediating role of employee followership and job satisfaction through conservation of resources theory. Review of Public Personnel Administration, 38(2), 167-192. https://doi.org/10.1177/0734371X16658334

43. Kalay, F. (2016). The impact of organizational justice on employee performance: A survey in Turkey and Turkish context. International journal of human resource studies, 6(1), 1-20. https://doi.org/10.5296/i jhrs.v6i1.8854 
44. Kalisch, B. J., Lee, H., \& Rochman, M. (2010). Nursing staff teamwork and job satisfaction. Journal of nursing management, 18(8), 938-947. https://doi.org/10.1111/j.1365-2834.2010.01153.X

45. Khan, H. U. Z. (2010). The effect of corporate governance elements on corporate social responsibility (CSR) reporting: Empirical evidence from private commercial banks of Bangladesh. International Journal of Law and Management, 52(2), 82-109. https://doi.org/10.1108/17542431011029406

46. Karim, N., Khan, R. A., \& Shamim, A. (2017). Determinants of job satisfaction in schools of Agha Khan Education Board, Karachi. Global Management Journal for Academic \& Corporate Studies, 7(1), 37.

47. Latsch, N. (2017). A Correlation Between Trust and Principal Leadership Behaviors in Rural Low SocioEconomical Schools (Doctoral dissertation, Northcentral University).

48. Leineweber, C., Bernhard-Oettel, C., Peristera, P., Eib, C., Nyberg, A., \& Westerlund, H. (2017). Interactional justice at work is related to sickness absence: a study using repeated measures in the Swedish working population. BMC public health, 17(1), 1-10. https://doi.org/10.1186/s12889-017-4899-y

49. Lim, B. T., \& Loosemore, M. (2017). The effect of inter-organizational justice perceptions on organizational citizenship behaviors in construction projects. International Journal of Project Management, 35(2), 95-106. https://doi.org/10.1016/j.ijproman.2016.10.016

50. Luthan, F. (1998). Organisasi Behavior (Eight Edition).

51. Mohsan, F., Nawaz, M. M., Khan, M. S., Shaukat, Z., \& Aslam, N. (2011). Are employee motivation, commitment and job involvement inter-related: Evidence from banking sector of Pakistan. International Journal of Business and Social Science, 2(17).

52. Moldavanova, A., \& Goerdel, H. T. (2018). Understanding the puzzle of organizational sustainability: Toward a conceptual framework of organizational social connectedness and sustainability. Public Management Review, 20(1), 55-81. https://doi.org/10.1080/14719037.2017.1293141

53. Mulyana, D. S., Matin, M., \& Rochana, S. (2020). The influence of organizational justice and perceptual support of organizations on Organizational Citizenship Behavior (OCB) teachers at SMA Negeri East Jakarta Area 1. IMPROVEMENT: Jurnal Ilmiah untuk peningkatan mutu manajemen pendidikan, 7(I), 33-51.

54. Mundhra, W. C. D. (2010). Intrinsic motivational canvass in the Indian service sector: An empirical study. Vision, 14(4), 275-284. https://doi.org/10.1177/097226291001400404

55. Nie, Y., Chua, B. L., Yeung, A. S., Ryan, R. M., \& Chan, W. Y. (2015). The importance of autonomy support and the mediating role of work motivation for well-being: Testing self-determination theory in a Chinese work organisation. International Journal of Psychology, 50(4), 245-255. https://doi.org/10.1002/ijop.12110

56. Ofoegbu, F. I. (2004). Teacher motivation: A factor for classroom effectiveness and school improvement in Nigeria. College student journal, 38(1), 81-90.

57. Okray-Kocabıyık, Z., \& Çakıcı, E. (2008). Burnout and job satisfaction in healthcare workers. Anatolian Journal of Psychiatry, 9 , 132-138.

58. Ongori, J. K., Iravo, M., \& Munene, C. E. (2013). Factors affecting performance of hotels and restaurants in Kenya: A case of Kisii County.

59. Ouyang, Z., Sang, J., Li, P., \& Peng, J. (2015). Organizational justice and job insecurity as mediators of the effect of emotional intelligence on job satisfaction: A study from China. Personality and Individual Differences, 76, 147-152. https://doi.org/10.1016/j.paid.2014.12.004

60. Park, Y., Song, J. H., \& Lim, D. H. (2016). Organizational justice and work engagement: the mediating effect of self-leadership. Leadership \& Organization Development Journal.

61. Qureshi, M. I., Iftikhar, M., Abbas, S. G., Hassan, U., Khan, K., \& Zaman, K. (2013). Relationship between job stress, workload, environment and employees turnover intentions: What we know, what should we know. World Applied Sciences Journal, 23(6), 764-770. https://doi.org/10.1108/LODJ-09-2014-0192

62. Rahman, K. U., Akhter, W., \& Khan, S. U. (2017). Factors affecting employee job satisfaction: A comparative study of conventional and Islamic insurance. Cogent Business \& Management, 4(1), 1273082. https://doi.org/10.1080/23311975.2016.1273082

63. Raziq, A., \& Maulabakhsh, R. (2015). Impact of working environment on job satisfaction. Procedia Economics and Finance, 23, 717-725. https://doi.org/10.1016/S2212-5671(15)00524-9

64. Rupp, D. E., Shao, R., Jones, K. S., \& Liao, H. (2014). The utility of a multifoci approach to the study of organizational justice: A meta-analytic investigation into the consideration of normative rules, moral accountability, bandwidth-fidelity, and social exchange. Organizational Behavior and Human Decision Processes, 123(2), 159-185. https://doi.org/10.1016/j.obhdp.2013.10.011

65. Saraih, U. N., MII, M. Z., Sakdan, M. F., \& Amlus, M. H. (2019). The influences of job performance, worklife balance and organizational justice on employees 'career satisfaction. Humanities \& social sciences Reviews, 7(5), 442-447. https://doi.org/10.18510/hssr.2019.7549

66. Scott, B. A., \& Judge, T. A. (2006). Insomnia, emotions, and job satisfaction: A multilevel study. Journal of Management, 32(5), 622-645.

67. Sharma, R. D., \& Jyoti, J. (2009). Job satisfaction of university teachers: An empirical study. Journal of Services Research, 9(2). https://doi.org/10.1177/0149206306289762

68. Sia, L. A., \& Tan, T. A. G. (2016). The influence of organizational justice on job satisfaction in a hotel setting. DLSU Business \& Economics Review, 26(1), 17-29. 
69. Skaalvik, E. M., \& Skaalvik, S. (2014). Teacher self-efficacy and perceived autonomy: Relations with teacher engagement, job satisfaction, and emotional exhaustion. Psychological reports, 114(1), 68-77. https://doi.org/ 10.2466/14.02.PR0.114k14w0

70. Skalli, A., Theodossiou, I., \& Vasileiou, E. (2008). Jobs as Lancaster goods: Facets of job satisfaction and overall job satisfaction. The Journal of Socio-Economics, 37(5), 1906-1920. https://doi.org/10.1016/j .socec. 2008.04.003

71. Song, L., \& Yang, L. (2020). Effect of Organizational Justice on Affective Organizational Commitment: Mediating Role of Perceived Organizational Support. Psychology and Behavioral Sciences, 9(5), 61. https://doi.org/10.11648/j.pbs.20200905.11

72. Tang, S. W., Siu, O. L., \& Cheung, F. (2014). A study of work-family enrichment among Chinese employees: The mediating role between work support and job satisfaction. Applied Psychology, 63(1),

$130-150$ https://doi.org/1 0.1111/j.1464-0597.2012.00519.x

73. Taylor, J. R. (2007). Toward a theory of imbrication and organizational communication. The American Journal of Semiotics, 17(2), 269-297. https://doi.org/10.5840/ajs200117222

74. Wang, H. J., Lu, C. Q., \& Siu, O. L. (2015). Job insecurity and job performance: The moderating role of organizational justice and the mediating role of work engagement. Journal of Applied Psychology, 100(4), 1249. https://doi.org/10.1037/a0038330

75. Yang, S. B., Brown, G. C., \& Moon, B. (2011). Factors leading to corrections officers' job satisfaction. Public Personnel Management, 40(4), 359-369. https://doi.org/10.1177/009102601104000407

76. Younus, S., Danish, R. Q., \& Rathore, K. (2020). Destructive Leadership and Counterproductive Work Behavior with Mediation Mechanism of Justice Perception: Evidence from Tanner Sector of Pakistan. International Review of Management and Marketing, 10(4), 83. https://doi.org/10.32479/irmm.9948

77. Zainalipour, H., Fini, A. A. S., \& Mirkamali, S. M. (2010). A study of relationship between organizational justice and job satisfaction among teachers in Bandar Abbas middle school. Procedia-Social and Behavioral Sciences, 5, 1986-1990. https://doi.org/10.1016/j.sbspro.2010.07.401 